\title{
EUGENIO LANDESIO TEÓRICO Y CRÍTICO DE ARTE
}

$\mathrm{POR}$

\section{XAVIER MOYSSÉN}

T a pintura del paisaje natural en cuanto tal, no hizo su aparición en $\perp$ el arte mexicano, sino hasta el siglo xix. Por las noticias históricas que poseemos, este género pictórico fue desconocido por las viejas culturas prehispánicas; el paisaje no aparece en las pinturas murales del altiplano, ni en las correspondientes a la zona maya; inútil empresa es buscarle entre los códices. Durante la colonia la pintura de paisaje no tuvo una vida independiente al lado de los grandes cuadros de asuntos religiosos, o en aquellos en que se retuvo la imagen de los personajes de la vida virreinal. El paisaje, dentro de las telas coloniales, muéstrase, las más de las veces, como un elemento de relleno y enteramente convencional, es decir, sin el carácter naturalista con que hoy le conocemos. El caso resulta razonable si se tiene en cuenta que para un mundo como el verreinal, la naturaleza física e incitante del paisaje circundante, poco era lo que interesaba; lo importante residía en la naturaleza metafísica de las cosas, en lo puramente imaginativo que tan bien se presta, justamente, para la especulación idealista tan necesaria en la iconografía religiosa. Además, téngase presente que el paisaje natural, dentro de la pintura española, no hizo su aparición sino hasta el siglo xix, con Carlos Haes; puesto que los dos deliciosos paisajes de la Villa Médicis que Velázquez pintó hacia 1650, en Roma, son una excepción que lamentablemente no tuvo mayor trascendencia. 
En algunas pictografías del siglo xvi, sobre todo en los mapas de relaciones geográficas, aparecen ciertas interpretaciones del paisaje mexicano, el cual fue retenido con una gran libertad de expresión. Sin embargo, el interés artístico que tienen estas pictografías, radica más en la ingenuidad y sencillez que tienen, que no así en la fidelidad del paisaje que se presume están representando. Don Carlos de Sigüenza y Góngora, en su Triumpho Parthenico, nos ofrece las interesantes noticias de dos pintores del siglo xvir que él cataloga como paisajistas: Angulo y Daza "cuyos países no tienen oposición, nos dice, sino hasta que se ponga a pintar la naturaleza"; ${ }^{1}$ desgraciadamente, de uno y otro, no conocemos más que esta referencia, pues de su obras nada se conoce. Algunos maestros de la pintura virreinal aprovecharon las lecciones que, sobre paisajes, les ofrecian los grabados que de Europa llegaban a sus talleres en número considerable, si bien es verdad que únicamente los utilizaban como fondo en sus composiciones de asunto religioso; tal fue el caso, entre otros, de Baltasar de Echave Ibía. ${ }^{2}$ Gonzalo Obregón dio a conocer, no hace muclio, tres telas coloniales en las que sus anónimos autores pintaron unas escenas de paisaje enteramente convencionales y llenas de fantasía, alejadas por lo tanto, de la poética realidad que ofrece el campo mexicano; estos tres cuadros, empero, constituyen las únicas obras de nuestra pintura virreinal en las que el paisaje tiene una vida independiente, pues al parecer fue el motivo o tema principal de estas curiosas pinturas. ${ }^{3}$ Pero insistamos una vez más, la belleza panteista y la vitalidad que el grandioso paisaje mexicano tiene en sus contrastadas manifestaciones no sirvió de tema específico para los pintores novoespañoles, nada logró inspirar a su sensibilidad de artistas. $Y$ lo dicho aqui puede hacerse extensivo, inclusive, a toda la pintura colonial de Hispanoamérica.

El descubrimiento y la interpretación plástica del paisaje mexicano, se realizó poco después de consumada la independencia política del país; cuando las puertas de éste se abrieron generosamente para todos aquellos a quienes la metrópoli española, con esforzada eficacia, había mantenido alejados de sus dominios americanos. Es entonces cuando llegan,

1 Folio 34.

2 Danes, Gibson. Baltasar de Echave Ibia. Some critical notes on the stylistic character of his art. En Anales del Instituto de Investigaciones Estéticas. Núm. 9. México, 1942, p. 15.

3 Obregón, Gonzalo. Los tres primeros paisajes pintados en México. En México ch la Cultura. Suplemento dominical de "Novedades". Núm. 654, Sep. 24, 1961. 
al lado de diplomáticos, banqueros, comerciantes y aventureros, varios artistas europeos que no tardan en quedar cautivados ante las variantes que les ofrece un paisaje virgen y esplendoroso, que pronto habrán de interpretar, con euforia romántica, en sus cuadros. El panorama paisajístico que se les presenta a la vista, está constituido por elevadas montañas, algunas de las cuales están coronadas por nieves eternas y, caso insólito, una de ellas tiene un penacho constante de humo; dilatados valles con distintos niveles en relación al mar, forman este paisaje en el cual hacen presencia con una vitalidad incontenible, las frondas lujuriosas de las selvas; tanto los ríos como las caídas de agua no escasean, máxime si hay coincidencia con las temporadas de lluvias. Pero serán el color y sobre todo la luz, los elementos que ejercerán una profunda influencia en la sensibilidad de estos pintores que redescubren, por decirlo así, al país. Johann Moritz Rugendas, el Barón Gros y Daniel Tomás Egerton, figuran a la cabeza de un grupo considerable de artistas, cuyas obras han sido estudiadas por don Manuel Romero de Terreros. ${ }^{4}$

La reorganización de la Academia de San Carlos, debida al decreto santanista de 1843, vino a propiciar, años adelante, la enseñanza de la pintura de paisajes entre los mexicanos. El director de la Academia, Pelegrín Clavé, fue consciente tanto de la importancia y belleza que ofrecía la naturaleza del país como de la necesidad de implantar, dentro de la Academia, la enseñanza de la pintura de paisajes como género especial; él mismo se había ocupado de dar ciertos conocimientos, pero como es lógico no bastaban, pues él no era un especialista en la materia y además sus actividades administrativas y docentes le tenían absorbido el tiempo. Para dedicarse a esta tarea, pensó que nadie estaba mejor indicado para ello que el paisajista italiano Eugenio Landesio, a quien él había conocido, años atras, en Roma. La elección de Clavé no pudo ser más atinada.

En la Italia del norte, en el pueblo de Altessano, Turin, nació Eugenio Landesio en 1810.5 En la necesidad de mejorar de situación, su familia

4 México visto por pintores extranjeros del siglo xIx. En Anales del Instituto de Investigaciones Estéticas. Núm. 28 México, 1959. p. 33.

5A Manuel G. Revilla se debe la mejor fuente documental sobre la biografía de Eugrenio Landesio. Consúltese: Obras del Lic. D. Manuel G. Revilla. Biografias (Artistas). T-I. Biblioteca de Autores Mexicanos. V. Agüeros, editor. México, 1908. En realidad, mucho de lo que sabemos sobre los artistas de nuestro siglo xIx, proviene de los escritos de este conspicuo historiador. Es de desearse que algún día se reediten sus Biografias y se den a conocer otros trabajos suyos que andan dispersos en diversas publicaciones de la época porfirista. 
se trasladó a Roma cuando él era muy joven. En medio de grandes problemas económicos, el artista que había en Landesio logró imponerse a las circunstancias que parecía habrían de decidir su vida; si las primeras lecciones de dibujo las recibió de su hermano mayor, las de pintura se las debió al paisajista francés Amadeo Bougeois. Mas por esa época había en Roma una amplia aceptación hacia la pintura llamada del paisaje histórico y el húngaro Carlos Markó era uno de sus máximos representantes. Gracias a la exquisita calidad de los dibujos de Landesio, Markó mostró especial interés para proteger al joven italiano; lo llevó a su taller donde le comunicó sus conocimientos hasta hacerle un paisajista consumado, adscrito, desde luego, a su escuela. Cuando el húngaro marchó fuera de Roma, Landesio era un pintor que ya gozaba de cierto prestigio; sus obras eran solicitadas favorablemente, el príncipe Marco Antonio Borghese, le encargó que pintara cuatro murales al fresco en su célebre Villa. Sus pinturas llegaban, incluso, hasta el Nuevo Mundo; en efecto, en la Exposición de 1853 de la Academia de San Carlos de México, se expusieron varios cuadros suyos, de los cuales la propia Academia adquirió algunos para sus Galerías de Pintura.

En la Academia romana de San Lucas, Eugenio Landesio conoció a Pelegrin Clavé, según se dijo; a él debió principalmente la invitación de la Junta Directiva de la Academia de San Carlos, para venir a impartir enseñanza de la Pintura de Paisaje y además las de Perspectiva y Ornato. No obstante que mucho Ie interesaba su clase de perspectiva, como veremos, se dedicó por más tiempo a formar pintores paisajistas; y si bien no logró establecer lo que se llama propiamente, una escuela de paisaje, no por ello dejó de formar excelentes pintores, entre los que se encuentran Luis Coto, Gregorio Dumaine, Salvador Murillo, Javier Alvarez, Miguel Jiménez y el más destacado del grupo: José María Ve. Iasco. De 1855 a 1877 Landesio trabajó en el país, si bien en ocasiones en medio de penosas dificultades, dadas las circunstancias históricas por las que se atravesaba. A él se debe la introducción de la pintura de paisaje en el arte nacional; aparte de los paisajistas que formó, debe tenerse en cuenta la obra que aquí realizó inspirado por la monumental belleza del paisaje mexicano. En la corte imperial de Maximiliano, éste le honró nombrándole Pintor de Cámara y a semejanza del príncipe Borghese, le pidió que pintara al fresco, en el Castillo de Chapultepec, seis grandes paisajes históricos con temas del México prehispánico, los cuales, por desgracia, no pudo ejecutar, pues con ellos se habría enriquecido nuestra pintura mural del siglo xix. Landesio retornó a Italia en 1877 , sin 
olvidarse de "la región más transparante del aire", hasta sus últimos días estuvo en correspondencia con su discipulo Velasco. ${ }^{\circledR}$ En París, a principios de 1879, inició el gran viaje inexcusable.

No vamos, en esta ocasión, a ocuparnos de la obra artística de Landesio, ya Justino Fernández lo ha hecho ampliamente y con la maestría crítica que se le conoce, por lo tanto, a lo dicho por él remitimos al lector. ${ }^{7} \mathrm{Si}$ queremos, en cambio, destacar la obra del artista italiano en cuanto a teórico y crítico de arte, pues ambas disciplinas Ias practicó con un gran sentido pedagógico y una encendida pasión polémica. Mas a estos aspectos de sus tareas literarias hay que sumar, también, el opúsculo que escribió como viajero o excursionista por el país, toda vez que está en relación con su criterio de artista, como habremos de ver. Este interesante aspecto de Eugenio Landesio, como crítico y teórico, ya ha sido tratado por Justino Fernández, aunque si bien es verdad no con el detenimiento necesario, pues de él se ha ocupado en obras de carácter general. 8

Pese al celo con el que Pelegrín Clavé había cuidado de la buena marcha de la Academia, Landesio debió encontrar, no obstante, serias dificultades teóricas relacionadas con la educación artística de los alumnos; para subsanar hasta donde fuera posible tal estado de cosas, se dio a la tarea de escribir él mismo un pequeño tratado que en mucho, seguramente, vino a ayudar en las enseñanzas de la Academia. En 1866 y por disposición que diera don Urbano Fonseca, director general de la Academia durante el gobierno de Maximiliano, las lecciones de Landesio fueron publicadas en un pequeño cuaderno que él dedicó, naturalmente, a la Academia Imperial de Nobles Artes de San Carlos; y lleva por título Cimientos del Artista Dibujante y Pintor. Compendio de perspectivas lineal y aérea, sombras, espejo y refracción con las no ciones necesarias de geometria. Aparte y en un formato mayor, se imprimieron Veintiocho Láminas Explicativas, las cuales no son otra cosa que un complemento gráfico a los Cimientos. Las láminas fueron litografiadas por tres de sus discípulos: Luis Coto, Gregorio Dumaine

6 Revilla, op. cit., p. 318.

7 Véase su Arte Moderno y Contemporáneo de México. Instituto de Investigaciones Estéticas. U.N.A.M. México, 1952, pp. 113-16.

8 El Hombre. Estética del Arte Moderno y Contemporaneo. Instituto de Investigaciones Estéticas. U.N.A.M. México, 1962. pp.. 42.45. Consúltese también la obra citada en la nota anterior. 
y José María Velasco; ${ }^{9}$ fuera de la función de academias que estas láminas tienen, hay algunas que poseen ciertas calidades por las cuales pueden figurar honrosamente al lado de las litografías artísticas deI siglo xIx; tal, por ejemplo, la número 18, que con su composición de perspectivas, luces y sombras, recuerda ciertos cuadros del periodo metafísico de Giorgio de Chrico, como atinadamente lo observara mi culto amigo don Felipe Teixidor. ${ }^{10}$

Estos Cimientos, escritos por Landesio, constituyen la forma más elaborada y elocuente de lo que era la enseñanza académica en los planteles educativos para los artistas del siglo pasado. Pero en esa enseñanza, forzoso es decirlo, si bien es verdad que había mucho de un tradicionalismo anticuado y nefasto con el que se acotaba lastimosamente li libertad creadora; no menos cierto es, también, que se daban los conocimientos y las bases para adquirir esa disciplina que es tan necesaria para la creación, pese a las presuntas genialidades que aseguran poseer los artistas. Seis partes, subdivididas en pequeños apartados de minuciosas explicaciones, forman este breve tratado teórico; al prólogo que lo antecede ofrece una idea clara sobre el contenido de las lecciones:

Dos clases se conocen de dibujo, y son: geométrico y perspectivo. El primero que se emplea para trazar las plantas, perfiles y cortes de los objetos, y del cual todos necesitan, no está sujeto a disminución perspectiva, manteniendo en sí sus dimensiones verdaderas, como si las percibiéramos, no por medio de los ojos, sino con el tacto. El segundo nos muestra los objetos o sitios del modo que suelen presentarse a nuestra vista; sean personajes, árboles, edificios, aguas, nubes, etcétera: disminuyen sus dimensiones conforme se alejan de uno, y según su oblicuidad con los radios visuales, ocasionando Io que se llama escorzo.

Todo lo que existe en la naturaleza bajo forma visible, sea cual fuere la materia de que esté formado, la estación, hora, lugar en que se nos presente, cualquiera la luz que lo ilumine, con que abramos los ojos y miremos, todo, sin excepción ninguna, está su-

9 Luis Coto, litografió las siguientes láminas: 6, 14, 19, 20 y 25; Gregorio Dumaine: $9,10,24,26$ y 27; el mayor número se debió a Velasco.

10 A la gentileza de don Felipe Teixidor debo el reproducir, en este trabajo, la fotografía autógrafa de Landesio que se incluye, la cual dedicó a Don José María Flores Verdad, un distinguido mexicano del siglo xix, cuya obra está en espera de estudio. 
jeto a las leyes inmutables de la óptica; es decir, a las de la perspectiva lineal y aérea, sombras, espejo y refracciones. Según la postura, el diferente nivel, con relación al que mira, y su mayor o menor distancia se dibujan las formas de los objetos: la diferente situación del sol o de cualquier otra luz natural o artificial, los ilumina de una u otra manera, proyectándoles sus sombras correspondientes, por medio de las cuales distinguimos los cuerpos y sus diferentes partes: los mismos se nos reproducen reflejándose en las superficies lúcidas según el ángulo de incidencia que hacen con ellas: los vemos romperse, doblarse y recogerse en sí mismos, penetrando en los cuerpos diáfanos, según el grado de oblicuidad y la dirección de los radios visuales con la superficie del transparente: finalmente la atmósfera les modifica la fuerza del claroscuro y colores, haciéndonos disfrutar más o menos según el grado de su pureza, de un hermoso y extenso horizonte. Claro está que no solo es útil para un pintor, el conocer y saber aplicar dichas leyes, sino necesario, indispensable.

No habiendo yo encontrado tratados que proporcionen conocimiento de un modo adecuado, tanto a la estrechez del tiempo en que el artista debe hacer estudios extensos y una práctica dificultosa, cuanto para no apagar el poético y fogoso entusiasmo de su imaginación, como sucede frecuentemente con explicaciones prolijas, me animé a escribir un tratado, que siendo breve, reuniese en sí todo lo indispensable al arte; correspondiendo de esta manera a la confianza con que me ha honrado la Academia de San Carlos, llamándome desde Roma para dirigir a los alumnos que se dedican a la pintura del paisaje y enseñar al mismo tiempo la perspectiva; lo acompañé a mayor claridad de 28 láminas y lo dividí en seis partes. Enseña la primera lo puramente necesario de geometría para entender y practicar las operaciones que se hallan en el curso; sigue la segunda enseñando la perspectiva lineal; como se trazan las sombras la tercera; a encontrar los espejos la cuarta; la quinta la refracción; acabando la sexta con la perspectiva aérea.

Estas nociones, que forman el verdadero y sólido cimiento del dibujante como del pintor, son las que ofrezco a la alabada academia en señal de mi distinguido aprecio; las que expuestas con pocas palabras y llanamente, podrán fácilmente adquirirse, si con empeñosa dedicación se aplican a ellas; con cuyas nociones fortalecidos, arrastrarán con acertada valentía los escollos que presenta este difi- 
cultosísimo cuanto bello y noble arte; serán con sus luminosos resultados, la honra y el adorno más hermoso de su patria, de la Academia en cuyo seno prosperaron, y viendo no frustrados mis celosos afanes, daré a Dios las gracias de haber conseguido el fin de mis deseos.

Al final de las lecciones y del tono cuasi científico que en ellas, puso, Landesio, el teórico, calla para dejar hablar, con idéntica sabiduría, al pintor naturalista que hay en él; así, al final de su tratado, entrega estas últimas palabras a aquellos alumnos que con provecho y paciencia le han seguido, haciéndoles notar que hay un gran maestro a quien ya podrán entender con positiva ventaja:

"habiendo expuesto los principios generales... hay lo bastante a fin de que sirva al joven artista como de llave para penetrar, entender y reproducir con menos dificultad, lo que le enseñará con su maravilloso lenguaje el gran maestro, la naturaleza, cuando esté delante de ella, lleno de admiración, con los pinceles y la paleta en la mano".

No era esta la primera obra que con fines didácticos publicara Eugenio Landesio, mucho antes de venir a América había publicado en Roma una carpeta con treinta y cuatro hermosas litografías, sin incluir la portada, las que dibujó entre 1835 y 1836 e imprimió en el taller litográfico de Wieller. ${ }^{11} \mathrm{El}$ tema general de estas litografias son diversos estudios que Landesio tomó del natural, sobre varios tipos de árboles y arbustos, mostrando, con detenida meticulosidad, las rugosidades accidentadas de los troncos y asimismo la delicadeza que hay en la tersura de las hojas de ciertas plantas. Algunas láminas, de un dibujo extraordinario, muestran varias composiciones de plantas entre rocas o estanques de agua. Pero en la mayoría domina la lección que se persigue dar, en cuanto a perspectivas y las consiguientes graduaciones de la luz. Un dominio perfecto en el manejo del lápiz tipográfico, muestra aquí Landesio, lo cual constituye un aspecto casi desconocido en su obra de artista. La carpeta es un verdadero atlas con temas apropiados a la pintura del paisaje, y dispuesto por lo tanto, para la enseñanza. Un gran auxilio debieron prestarle estas láminas dentro de su taller mexicano de la Academia de San Carlos.

$11 \mathrm{Raccolta} / \mathrm{di} / \mathrm{trentaquatro} / \mathrm{piante} /$ designate dal vero $\mathrm{c} /$ litografate da/ Eugenio Landesio/ Roma/ MDccxxxvi. 
Después de la aparición de los Cimientos, Landesio se dio de nueva cuenta a las tareas literarias. En esta ocasión escribió sobre la importancia que tiene la pintura de paisaje, sobre la introducción de este género en México y las obras que aquí él mismo había ejecutado; escribió respecto a sus enseñanzas en la Academia y del número de alumnos que habian aprovechado sus consejos y lecciones; nuevamente insistió en la importancia que para todo artista tiene el buen conocimiento de la perspectiva. Mas no obstante todo lo anotado, se puede afirmar que lo que hizo en realidad, fue el escribir la historia de su labor como maestro en México y la importancia que él confería a su obra; él mismo nos dice que escribió "para que conste que no de palabras solamente enseñé, sino de hecho y con entereza..." Tal parece que presentía que en fecha no lejana tendría que justificarse, puesto que las cosas públicas cambiaban notoriamente. A mediados de 1866 entregó las primeras partes de su nueva obra para que se publicaran en el periódico imperialista El Mexicano; ${ }^{1 \ell}$ por razones de fácil entendimiento, suspendió las entregas mucho antes de que el citado periódico dejara de circular por la caída de Maximiliano. Sin embargo, para el año siguiente, su escrito fue impreso completo en forma de cuaderno, aparcció bajo este título: La Pintura General o de Paisaje y la Perspectiva en la Academia Nacional de San Carlos. Para la fecha en que el cuaderno salió de la imprenta, las cosas ya habían cambiado, la Academia, por lo tanto, había dejado de ser Imperial, para transformarse con toda propiedad en Nacional.

Tanto un consumado conocedor de su oficio como un teórico sistemático, muéstrasenos Eugenio Landesio en las breves páginas de esta obra. Su estilo si no es esmerado por lo menos resulta ameno, breve y certero, y en ocasiones nos muestra que no estaba clesprovisto de cierta ingenuidad; por lo demás, las ideas estéticas insertas aquí son una buena demostración de los gustos y enseñanzas que privaban en las academias de bellas artes en el siglo pasado. Asienta, por principio, en qué consiste la pintura general o de paisaje, cuáles son sus ramos, secciones y géneros. Unas cuantos líneas entresacadas del texto, nos proporcionarán una idea precisa de las teorías y enseñanzas del célebre paisajista: "La Pintura General o de Paisaje, es la representación de todo lo que puede existir en la naturaleza bajo forma visible y artística... La pintura

12 Aparecieron en tres entregas, correspondiendo a los números 56,57 y 58 del Tomo 1. 
general comprende dos ramos, que son: Localidades y Episodios; al primero pertenecen las secciones Celajes, Follaje, Terrenos, Edificios; y al segundo pertenecen: Historia, Escenas populares, Escenas militares, Escenas familiares, Retratos y Animales". A continuación hace una subdivisiòn detallada de las secciones que forman las dos ramas citadas y concluye con que "el pintor general debe conocer dos ramos: Localidades y Episodios, que es lo mismo que decir: Paisaje, considerado separadamente, y Figura humana y Animales (esto último tomado como pintura particular). De suerte que la pintura general y particular, son distintas, independientes una de otra, aunque hermanas, y hermanas gemelas; y con todo que las dos pueden tratar un mismo asunto, no se sustituyen, exponiéndolo cada cual de un modo distinto, bajo otro punto de vista". Pero, fiel al género pictórico que practica, no puede menos que esforzarse para tratar de convencer que la pintura general o de paisaje, como la llama, es superior a la particular, porque "siempre abarca el doble fin de dar una completa idea de las bellezas y caracteres naturales y artificiales que constituyen la localidad, como de sus moradores, ya exponiéndolos en asuntos familiares y sencillos, ya con gravedad e interés histórico".

En el capítulo que titula Estudios del pintor general, están comprendidas todas sus teorías sobre la enseñanza, así como las exageradas cualidades que a su juicio, debían de reunir todos aquellos que pensaran dedicarse al estudio de la pintura: "El joven que quiera volverse pintor General, supuesto que existan en él todas las calidades que se requieren, es decir: genio, entusiasmo, constancia, diligencia sin niguna sombra de pereza, buena conformación de ojo, apta a leer las finuras de Ias formas y de los colores, junto a un fina sensibilidad, de alma y proporciones para que pueda dedicarse enteramente al estudio sin pensar en la subsistencia; será bueno que después de aquellos estudios que son comunes a un joven fino, cursar matemáticas, física, química e historia natural". A continuación fija, con riguroso detalle, las normas que debe seguir el estudiante durante el proceso de su formación. Y concluye la parte teórica con el problema que tanto le preocupaba: el de la perspectiva y su enseñanza; a juzgar por lo que anota su preocupación estaba bien fundada: "La perspectiva no es un género ni una sección de la Pintura general, como muchos creyeron y creen todavía, sino una ciencia que sirve de base a todos los géneros de pintura, tanto general como particular... Los cuadros que equivocadamente han llamado y llaman todavía Perspectivas, son todos los pertenecientes a la sección 
Edificios; porque muchos creyeron y creen, que solo para esta clase de cuadros sea necesario el conocimiento de la Perspectiva, lo que es falso, porque sea cualquiera el asunto que se represente en un cuadro... debe ser conducido perspectivamente... (por lo tanto) la Perspectiva debe ser igualmente estudiada y conocida (por) los pintores..."

Respecto a la introducción académica de la pintura de paisaje en México, Landesio lleno de orgullo asienta en las páginas de esta obra, que fue Ilamado desde Roma para venir a enseñarla conjuntamente con la clase de perspectiva, en la Academia de San Carlos; hace un elogio de su labor de maestro así como una minuciosa descripción de los cuadros que ha pintado desde su llegada; pero todo lo dice en tercera persona, con una ingenuidad que no siempre convence por la intención un tanto velada que puso al escribir, según puede advertirse. En el mismo escrito ofrece una relación de aquellos alumnos que sobresalieron en la disciplina que les impartió y, como es lógico suponer, los mejores elogios se los lleva el que fue su discípulo predilecto, el que andando el tiempo habria de superarle, no sin cierto orgullo para él como maestro: José María Velasco.

Si el contenido de La Pintura General o de Paisaje... es interesante por las teorías de Eugenio Landesio y asimismo por las noticias de carácter histórico que contiene, su importancia se acrecienta por las ideas que el maestro tenía sobre la crítica de arte y sobre los escritores que la ejercían. En realidad, en la introducción que escribió para su opúsculo, existe toda una crítica estética enderezada tanto hacia los métodos de enseñanza, como en contra de los pintores y críticos de arte; sobre estos últimos, muy en particular, se lanza contra ciertos escritores, literatos los llama, que sólo siembran, a su juicio, la confusión sobre los valores específicos de la obra de arte. No está de más anticipar que tal crítica la enfocaría, años adelante, en contra de Ignacio Manuel Altamirano, quien aparte de su labor crítica y constructiva en favor de una literatura de carácter nacional, ${ }^{13}$ se ocupaba, también, de las artes plásticas. He aqứ las críticas que Landesio formuló en contra de la enseñanza, los pintores y los críticos de arte:

No hay arte, yo creo, en que se usen más voces equivocadas como en el de la Pintura, lo que en gran parte se debe atribuir a la omi-

13 Martínez, José Luis. La Expresión Nacional. Letras Mexicanas del siglo XIX. Imprenta Universitaria. México, 1955. pp. 73 a 121. 
sión de estudios preparatorios, que su enorme y complicada extensión exige.

Por desgracia, pocos son los pintores que unan a la práctica la teórica, mientras que un gran número hay llenos de preocupaciones y otra cantidad casi puramente manuales, los que son más bien artesanos que artistas. Estos últimos, trabajan al acaso, niegan las teorías que dicen no existir; cuyas falsas ideas son infundidas de sus maestros, los que hallándose también a oscuras, ya sea por no creer en ellas, ya sea por no tener valor para aprenderlas; y temiendo ser superados y perder el concepto de sus discípulos, prefieren negarlas y decir que no existen, que son imposturas.

Coadyuvan también grandemente a este mal, a la confusión, aquellos literatos que sin tener una idea clara de lo que es Pintura y mucho menos lo que es ser pintor, quieren discurrir y sentenciar sobre ella, los que en lugar de aclarar aumentan más y más las tinieblas.

¿Será acaso posible, que sin haber tenido un pincel en la mano ni un lápiz, puedan hablar de pintura; de la soltura de pincel, que solo practicando mucho se entiende; de la pureza del dibujo, que a pocos pintores es dado conocer; de las líneas, que entre los mismos artistas pocos hay que las entiendan; del efecto, entonación, armonía sin saber en qué consiste? Cierto que no. Sin embargo, sentencian con una seguridad que raya en el descaro, en la impertinencia, sobre el mérito de los cuadros y de los artistas; alaban, a veces, y elevan hasta los cielos una miserable cosa, despreciando y echando a la basura otra de mérito, guiados no de otra ley, de la de su capricho, o siguiendo el parecer de otra persona que aprecian como conocedora sin serlo; y haya aun sido un pintor: pero, ¿tenia este pintor tanta capacidad y saber como el que hizo el cuadro que juzgaba; era del mismo ramo, de la misma sección, del mismo género; había, dicho pintor, ejecutado cuadros, y éstos por sí solo, o bajo la dirección de otro; y si dijo por si solo, estáis ciertos de que no haya habido dirección oculta? porque a veces se aprovecha del saber y generosidad de otro, pero ocultamente, y sacados que se hallen de apuro le retribuyen también acultamente, pero desprestigiándole. Además suele jugar en estos casos el espíritu de rivalidad y enemistad.

El decreto del 5 de octubre de 1873, que declaró constitucionales las Leyes de Reforma, obligó a Eugenio Landesio a renunciar a su clase de 
DOI: http://dx.doi.org/10.22201/iie.18703062e.1963.32.751

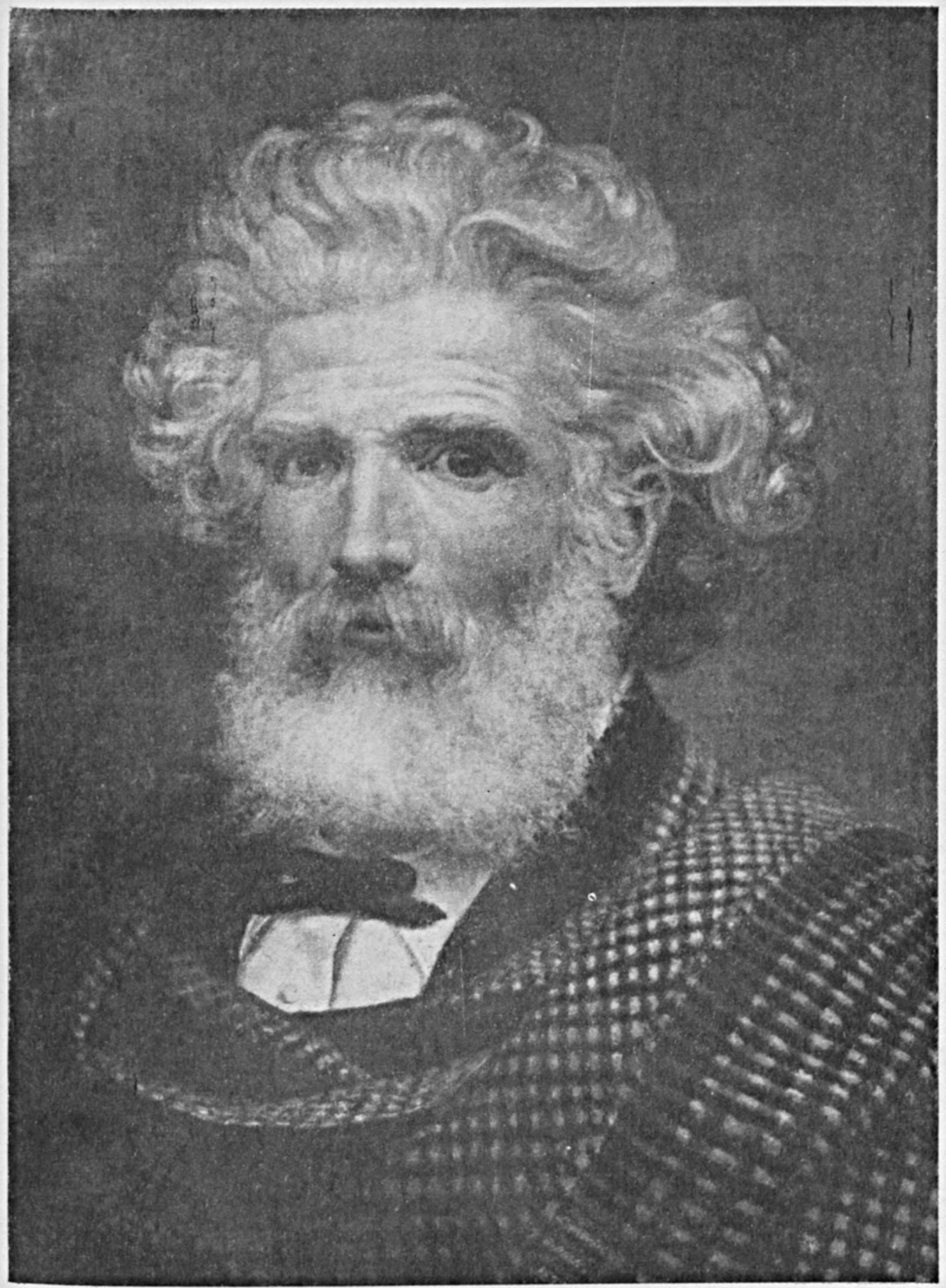

Eugenio Landesio, Autorreirato. Óleo. México, 1873. 
DOI: http://dx.doi.org/10.22201/iie.18703062e.1963.32.751
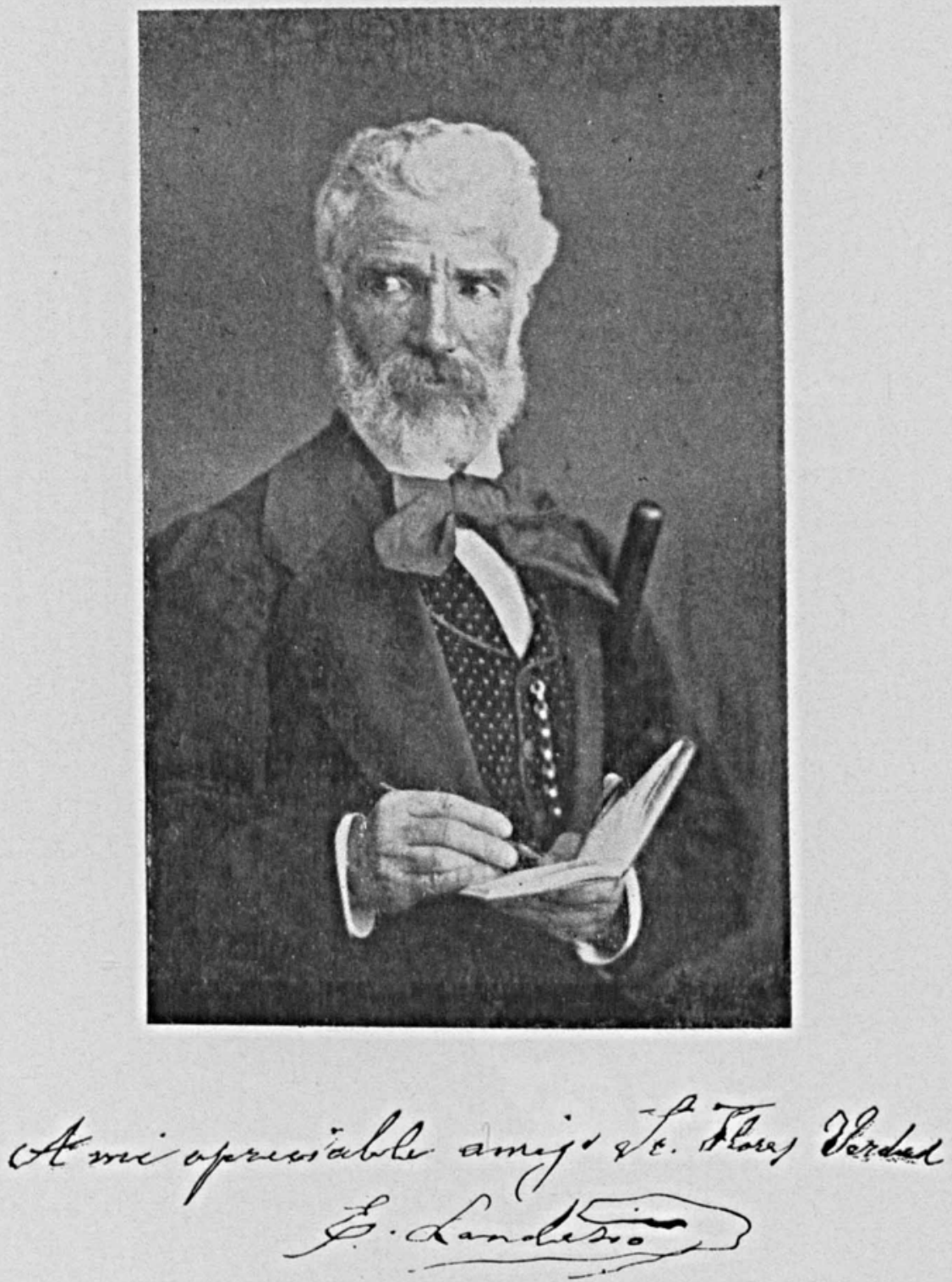

Eugenio Landesio. Fotografía dedicada a Dn. José María Flores Verdad. 


\section{I M I E N T OS \\ $11: \therefore$ ARTISTA,}

DTIUJANTE Y PINTOR.

COMIPENDIO

DE

TERSTTCTIVA IINEAL Y AEREA,

SOMDAAS, ESTEJ AS I REFHACCIONCONIAS NOCIOABB NECESARIAS liF GEOMETRIA.

\section{$3030 \times \mathrm{GAOO}$}

$\Delta$ ILd

A

DE

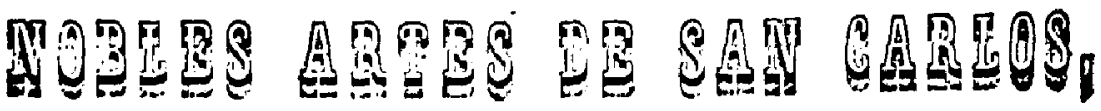

Tot $\mathrm{HT}$.

SRÓFESOR DE IINTURA TIE PAISAJE T DE PEISPLCTIYA,

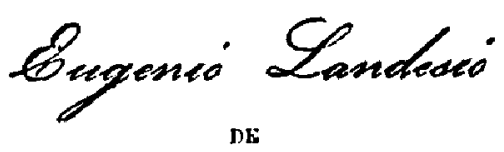

TURINO.

MEXICO

1866 . 


\section{LA \\ PINTURA}

GENERAL 0 IJE PAISAJE

Y LA

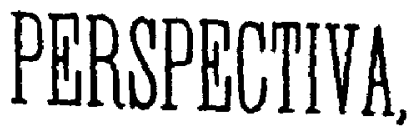

Ji:

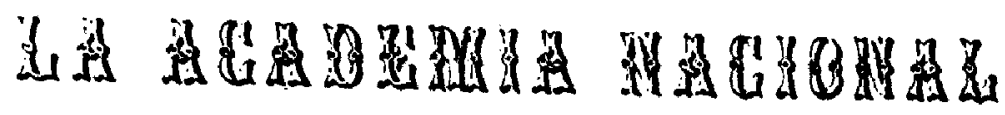

It

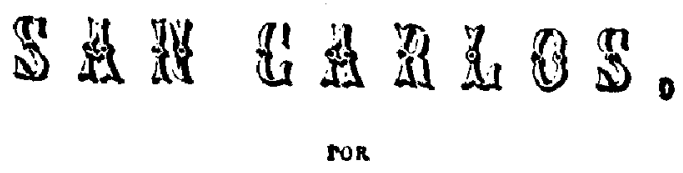

Eregenió Leanktusia,

עx

'IURIN.

IM EICO.

1867.

Iniprenta de Inara, calle de in Palma númo. 4. 


\section{ESCURSION}

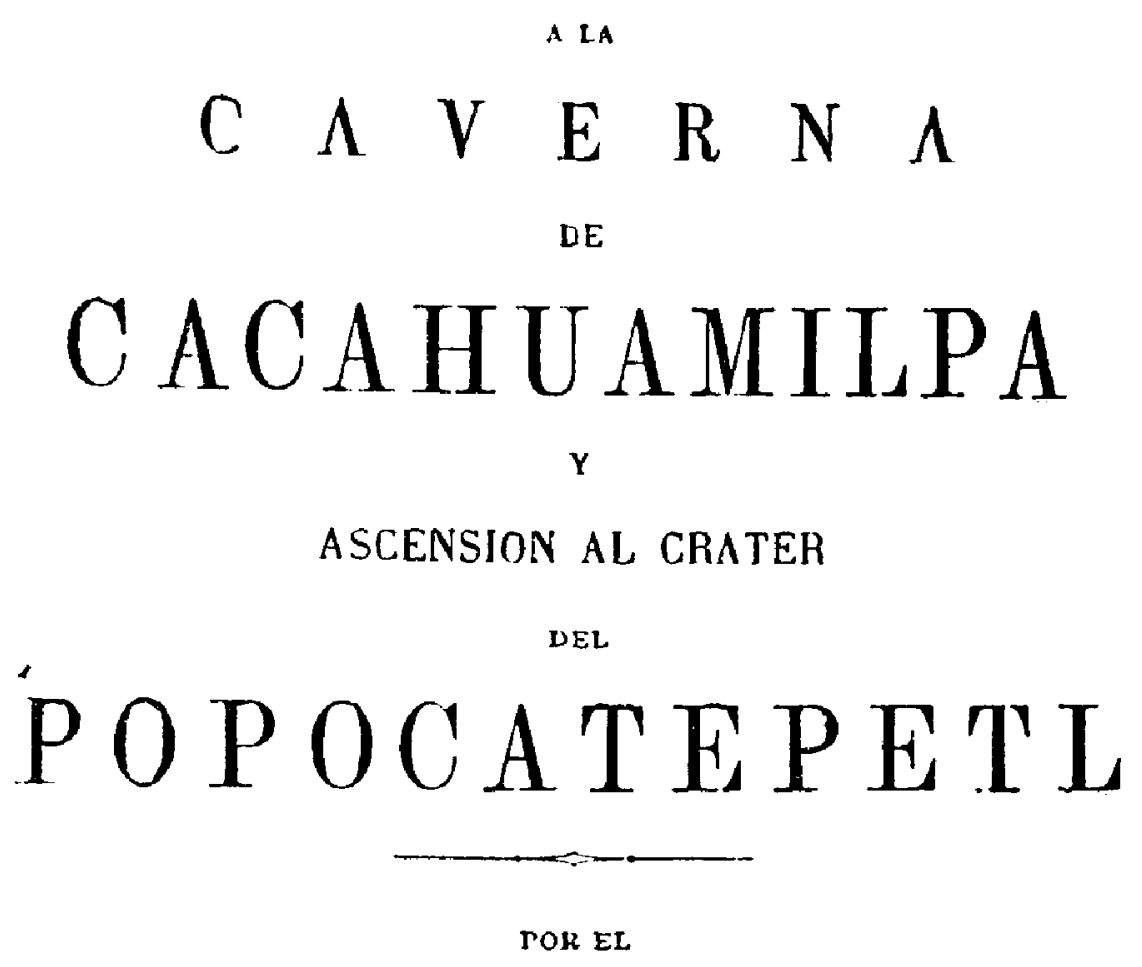

PROFESOR DE IINTURA GENERAL Ó DE I'AISAJE

DE LA ACADEMJA NACIONAI, DE

SAN CARLOS

Snagemio Eundesio

I'TALIANO

cserifa cn casiellano por el misina

M E X I C 0

1868.

IMII. DEL COLEGIO DEI, TECPAM 
DOI: http://dx.doi.org/10.22201/iie.18703062e.1963.32.751

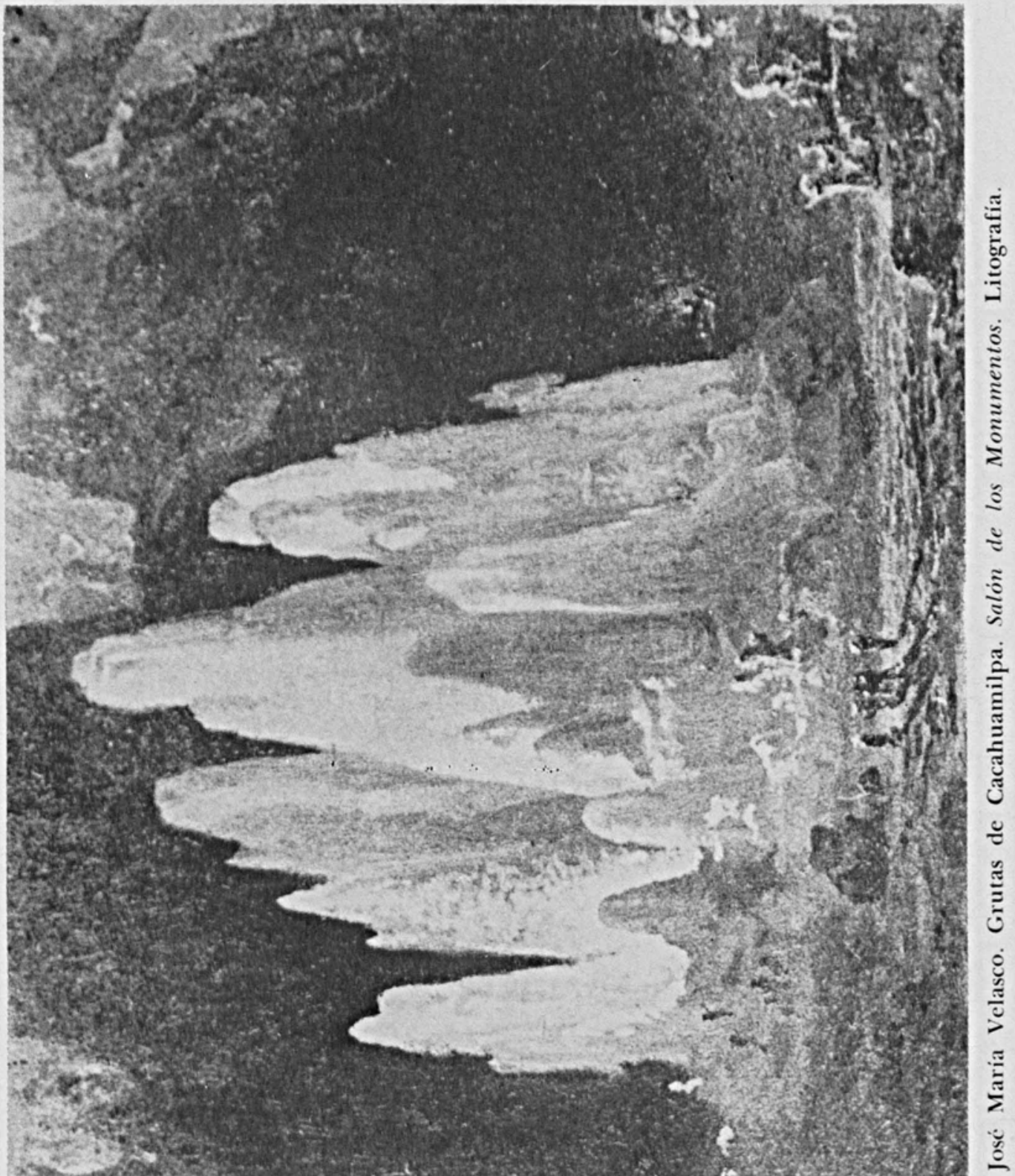

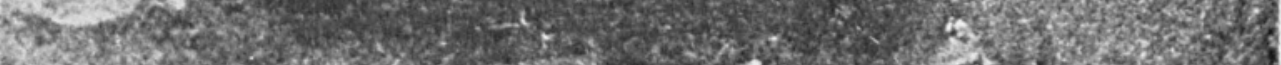

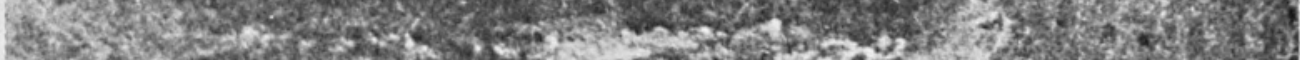

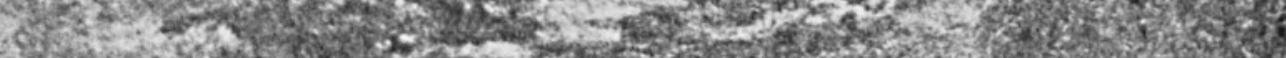

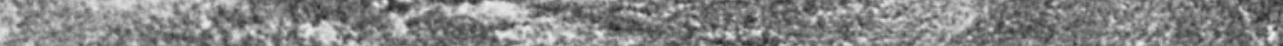
Mrex 2.

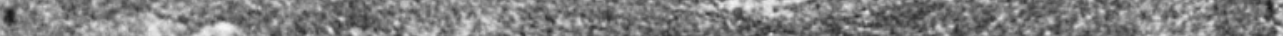

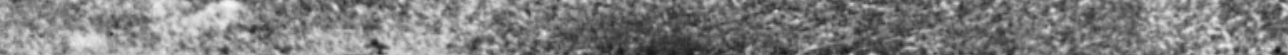


DOI: http://dx.doi.org/10.22201/iie.18703062e.1963.32.751

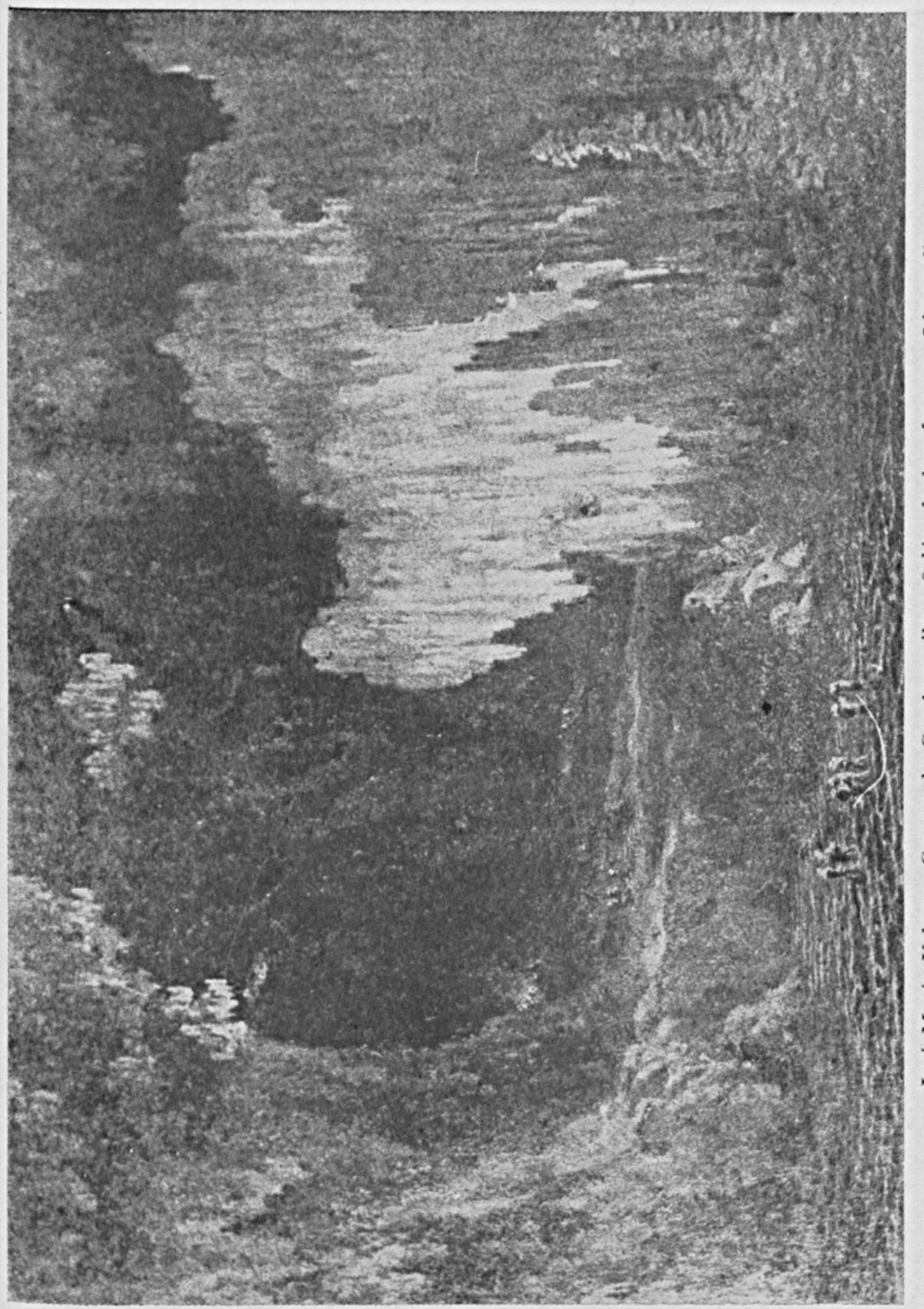

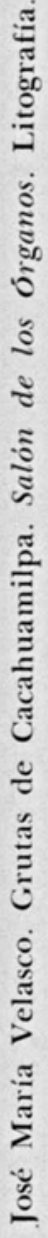


DOI: http://dx.doi.org/10.22201/iie.18703062e.1963.32.751

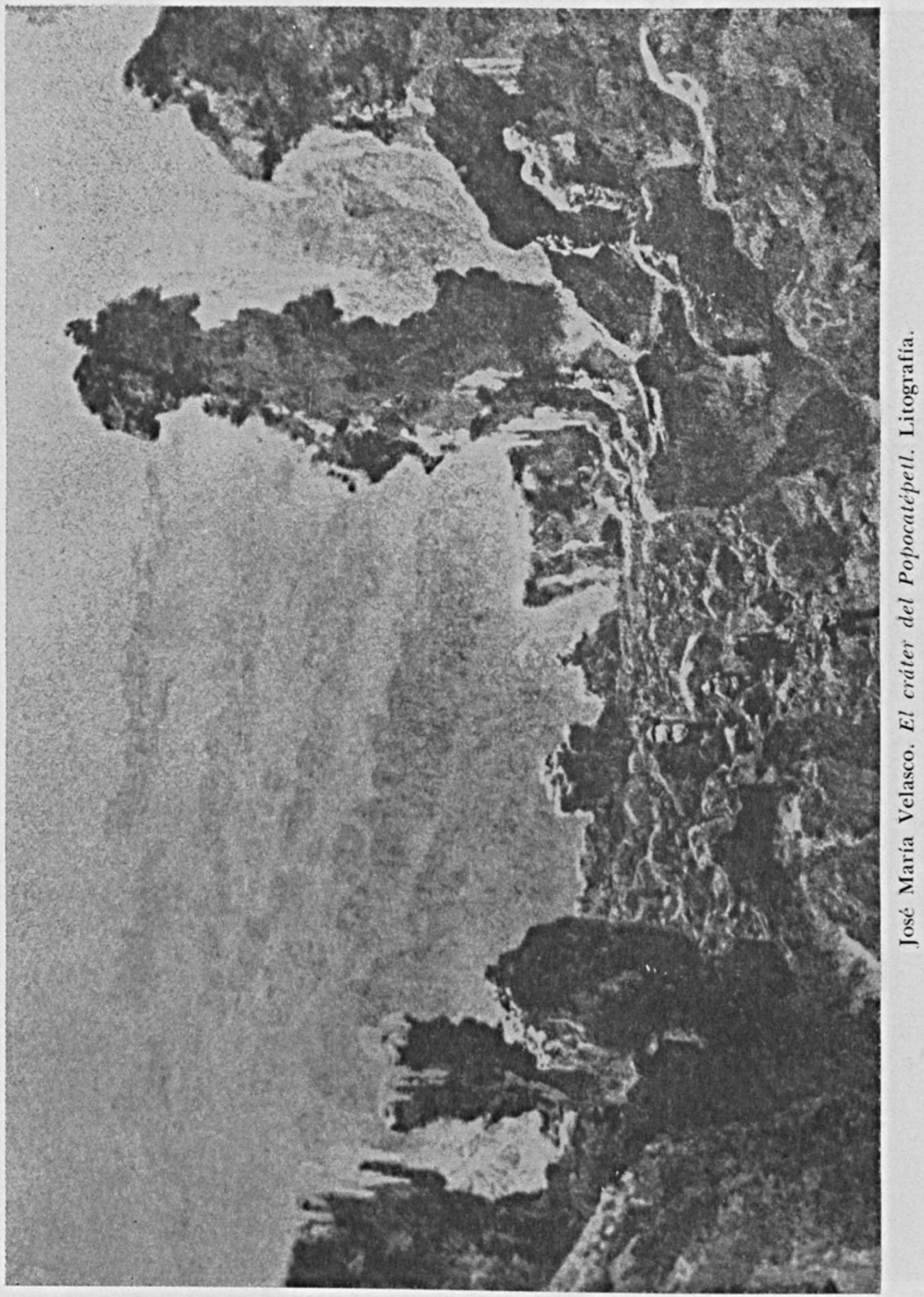


pintura de paisaje, atendida por diecinueve largos años, ${ }^{14}$ toda vez que él se negó a protestar el cumplimiento de las citadas leyes, atendiendo a las razones personales de sus creencias religiosas.

Para ocupar la vacante que el maestro dejara, varios periodistas liberales propusieron a uno de sus discipulos, a Salvador Murillo, quien contó, ademảs, con la ayuda desmedida de Ignacio Manuel Altamirano. Por su parte Landesio se preocupaba porque le sucediera aquél que, sin duda, era el más indicado para ello, su caro alumno José María Velasco. Los tiempos eran de turbulencia política y propicios por lo tanto, para las controversias ideológicas, a las que no podía escapar, por supuesto, el arte mismo. El asunto de la sucesión académica dio lugar a una enojosa controversia entre Altamirano y Landesio, la cual reproduciremos integra adelante, pues nos dará oportunidad de mostrar la apasionada crítica que hizo el pintor a la no menos furibunda crítica del novelista.

Un papel de primera importancia es el que corresponde a Ignacio Manuel Altamirano, dentro de la crítica artística del siglo xix. Su labor dentro de este campo ha sido estudiada por Justino Fernández; ${ }^{15} \sin$ embargo, soy de opinión que aún es mucho lo que se desconoce de la crítica de arte que Altamirano escribió, y que será de indudable interés el llegar a verificar si existe cierta continuidad o analogía de criterio, entre ésta y la labor teórica que desarrolló en la literatura. Dos de las transcripciones que se publican en seguida, aparecieron en La Tribuna, periódico del que era responsable directo el propio Altamirano; en los dos artículos no figura el nombre del autor, es decir, son anónimos, pero ello no es obstáculo para identificarlos como de la pluma del famoso escritor; el estilo es semejante al de su crítica literaria, en ellos se encuentra la misma ironía y vehemencia política, la misma soltura, a veces un tanto irreflexiva, con que condenaba o exaltaba, aquello que había movido su pasión o sus intereses en favor de la cultura nacional; además Revilla nos ha dejado la noticia de que fue Altamirano el autor de los mismos. ${ }^{16}$

La crítica que hace en esta ocasión Landesio, en principio obedece a los lineamientos teórico-académicos que ya le conocemos; la condena

14 Cinco años atrás, en 1868, había dejado la clase de Perspectiva por haberse abstenido de protestar en contra de la Intervención. Francesa.

15 Véase: De la critica de arte en México. Ignacio Manuel Altamirano (1880). En Letras de México, México, 1940. 11, 15. Y además El Hombre..., pp. 53-60.

16 Revilla, op. cit., p. 312. 
que lanza contra los literatos que escriben sobre artes plásticas, aparece de nueva cuenta, y declara que los términos que estos suelen utilizar, le parecen propios de aquellos que han "padecido una alucinación muy poderosa". Pero en el fondo también hay una crítica que se debe a razones de carácter ético, como verá el lector.

En el número 14 de La Tribuna, correspondiente al 24 de enero de 1874, publicó Altamirano el siguiente comentario, lleno de intenciones polémicas, bajo el sencillo título de:

Salvador Murillo.-Sabemos que el joven artista Salvador Murillo, será nombrado director de la cátedra de paisaje en la Academia Nacional. Mucho nos alegramos. Murillo no es un artesano del color; no es para él la pintura un mecanismo; no se contenta como algún paisajista, cuyos cuadros hemos visto en la exposición última, con figurarse que Landesio es la Naturaleza, y con copiar a éste sin cuidarse de la realidad; no, Murillo ha educado su gusto en otra escuela y con otras aspiraciones. Pertenece a lo que en Europa se llama pre-rafaelista, es decir, a la escuela que busca la verdad en la naturaleza, seguro de que la verdad en Ia naturaleza es el más encantador de los sueños. Es de los que no cambian por los más estudiosos juegos del pincel, que sólo sirven para hacer cuadros bonitos, los efectos de un rayo solar corriendo en estalactitas de oro, por las parásitas de un ahuehuete, y reverberando en los charcos de agua, evaporándose en las musgosas rocas del Valle.

No es, por esto, un copista servil; nadie sabe soñar como él, delante de un paisaje, nadie ejecuta con más brío, ni suaviza sus toques con mayor intuición de los secretos maravillosos de esa hada divina de la creación, que se llama la luz.

El arte mexicano y la Academia, están de enhorabuena.

Las alusiones y la crítica eran sumamente claras para guardar silencio, por lo tanto, la contestación de Landesio no se hizo esperar, la remitió al periódico La Iberia, y apareció en el número 2091, correspondiente al 4 de febrero de 1874, repitiendo el encabezado del artículo anterior:

Salvador Murillo.-Con este encabezamiento he leido en el número 14 de La Tribuna un artículo el cual hubiera querido pasar por alto; pero como se ataca en él, mi escuela, al discípulo que 
más la honra, resultando además en menoscabo del honor y lucimiento de la Academia y de la nación mexicana toda, culpa seria en mi si no alzara la voz para impedir tan injusto atropellamiento.

Parece que el autor del artículo ha padecido una alucinación muy poderosa; solo así pudo ver "los efectos de un rayo solar corriendo en estalactitas de oro por las parásitas de un ahuehuete, y reverberando en los charcos de agua evaporándose en las musgosas rocas del Vafle". ¡Qué le parece a usted! Conocería igualmente " a la escuela que busca la verdad, seguro de que la verdad en la naturaleza es el más encantador de los sueños" que esta escuela es "la que en Europa se llama pre-rafaelista". Conoceria también que el señor Murillo "es de los que no cambian por los más estudiados juegos de pincel que sólo sirven para hacer cuadros bonitos, a los rayos solares que corren en estalactitas de oro, etcétera, y eso porque ha educado su gusto en otra escuela y con otras aspiraciones". La misma alucinación haríale conocer no ser su estrella artística "un artesano del color" y que no siendo la pintura para él un mecanismo, no se contenta, como algún paisajista cuyos cuadros hemos visto en la Exposición última, con figurarse que Landesio es la naturaleza, "y con figurarse" que copió "a éste sin cuidarse de la realidad". Vio aún más allá, vio que Murillo no es un "copista servil", y que "nadie como él sabe soñar delante de un paisaje" aunque en cuanto a soñar le gane y con mucho el autor del artículo; sin embargo, no hemos de reñir por eso. "Y nadie, continúa el articulista, lo ejecuta con más brío, ni suaviza sus toques con mayor intuición de los secretos maravillosos de esa hada divina de la creación que se llama la luz".

No, amigo mío, padeció usted una equivocación y muy grande; soñó usted así como quiso usted pintar soñolienta a su estrella. El señor Velasco, el autor de los cuadros que usted desprecia y sin razón ninguna, luce por el contrario, y honra mi escuela, La Academia y a México; no es copista, ni servil, y ni pedante. Si sigue mi escuela es porque la reconoce buena, verdadera, no de rutina, sino basada sólidamente en teorías: si me aprecia y me cree es porque conoce que jamás le he dicho una cosa por otra, que jamás le he engañado, y porque ha visto que si he padecido algún error, y habiéndomelo hecho observar, y conocida su existencia, nunca lo he impugnado ni dejado incorrecto.

Velasco observa mis teorias: sin embargo, sus pinturas son origi- 
nales, porque pinta desarrollando ideas suyas, introduciendo otros objetos, o mostrándolos bajo otros aspectos; pero siguiendo siempre las leyes de que consta la naturaleza misma, de las cuales no puede uno apartarse un momento so pena de cometer disparates, so pena nada menos, que de soñar "delante de un paisaje"; de pintar "charcos evaporándose en las rocas musgosas del Valle".

Además hace usted muy poco honor al señor Murillo pintándole, y sin saberlo, un ingrato, pues ¿en dónde estudió la pintura? en la Academia de México: ¿quién fue su profesor? el mismo que enseñó al señor Velasco y a tantos otros, yo mismo: ¿por qué abandonó Ia Academia? por un infundado rencor; la misma causa de otros que la abandonaron también antes que él; y ¿queréis saberlo? porque yo prefería al de más mérito, cosa muy natural de que el maestro prefiera al que hace mayor provecho y dé más honor a su escuela.

No se crea por eso que si defiendo a Velasco sea enemigo de $\mathrm{Mu}$ rillo, que le defendiera igualmente si le creyese merecedor. Ninguno de mis discípulos puede con justa razón inculparme de haber desatendido, o que le haya hecho alguna injusticia. El mismo Murillo, si quiere decir la verdad, debe confesar haberle yo reconvenido repetidas veces a causa de su obstinación en querer pintar para el comercio haciendo copietas de ningún estudio; picándole yo de continuo a que se dedicara seriamente al estudio de la naturaleza. Murillo no falta de disposición y de algún mérito, pero sí de abnegación y de voluntad, cuyas cualidades, teniéndolas Velasco, hizo que aunque menos antiguo en el estudio lo adelantara, pudiéndola hacer al presente de maestro.

Concluyo finalmente que si se trocara al señor Velasco por el señor Murillo en la dirección del ramo de Pintura general, ni "el arte mexicano, ni la Academia estarán de enhorabuena”, sino al contrario, estarán de pésame.

Así es que, amigo mío, menos sacos y más nueces, menos pompa y más abrigo, menos humos y más sustancia.

E. LANDEsio

En la entrega de La Tribuna, correspondiente al 4 de febrero de 1874 , Altamirano contestó a Landesio en el tono que el lector verá en seguida:

Un párrafo de La Tribuna en que felicitábamos a la Academia de Bellas Artes por la adquisición del excelente paisajista, el señor 
Salvador Murillo, ha dado motivo a un vehemente remitido del ex-profesor Landesio, en que traba lid descomunal con el suelto de nuestra gacetilla, y después de triturarlo a su sabor, usando de la terrible clava de la ironía y del coraje, asienta estas conclusiones: el nombramiento de Murillo sería una desgracia para la Academia; el nombramiento de Velasco (mi discípulo querido) sería una felicidad. Razones: Murillo se apartó de mí por rencor; Velasco me cree y me aprecia.

¿Nos permitirá el buen señor Landesio que no nos demos por convencidos? En primer lugar, excelente señor Landesio, el que Murillo se haya apartado de usted por rencor y el que Velasco se haya quedado por cariño, nada significa para la pintura de paisaje. Supongamos que usted como es italiano, fuese usted un buen mexicano, y que hubiera usted, en horas amargas para nuestro orgullo y nuestra honra, oído a su profesor que se llenaba la boca con el panegírico eterno de la intervención francesa y de SS. MM. II.; ¿no es cierto que habríase ido formando en usted cierta aversión por ese enemigo de su país y en éste cierta hostilidad por el joven insurrecto? y si a esto agregamos la independencia en el carácter que no le permitía doblegarse a las reglas que dan por resultado copiar a Landesio en vez de copiar a la naturaleza ¿no es verdad que tendría usted razón en separarse del profesor? ¡Oh! buen señor Landesio, bien sé yo que ninguna de estas cuestiones políticas tiene que ver con el paisaje; pero en cambio mucho tienen que ver con el remitido de usted.

Usted es un buen pintor, señor Landesio, y si carece usted de genio, y si no sabe soñar delante de un paisaje (cosas de poetas señor Landesio, no se enoje usted) en cambio es usted un colorista habilísimo; nadie como usted sabe inventar una nube, y exceptuando el arco-iris, todo lo sabe usted pintar. Pero esa escuela no es del gusto de todos, señor Landesio, ¿me permitirá usted decírselo? Nunca hemos visto el Valle de México como usted lo ha pintado; en cambio, creemos que si no lo hemos visto tan coqueto, si nos ha parecido más bello. Y si usted amanera un poquito señor Landesio ¿qué diremos de los que lo imitan a usted? Para esos pasa la naturaleza al través del alambique de las reglas científicas de usted y los cuadros salen muy fatuos, y lo fátuo se aleja perfectamente de la naturaleza.

Damos punto señor Landesio, rogando a usted no se enoje tanto, 
ni se le figure que nos dan mucho cuidado sus furias olimpicas. Murillo está juzgado por personas competentes y los tiros del antiguo pintor de Cámara no pueden herirle. En cuanto a los pésames de usted, allá veremos; así como no dejamos de comprender que no carece usted de razón en sentirse hasta cierto punto molesto con nuestras "estalactitas de oro", formadas por la luz y los "charcos de agua que se evaporan entre el musgo" estas son blasfemias y herejías (contra el sentido común dirá usted, en quien parece hay más de un Aristarco), y replicaremos nosotros, señor Landesio, haciendo plena justicia a su mérito, que el sentido de usted no es de lo más común que hayamos conocido.

Al segundo escrito de Altamirano, Eugenio Landesio ya no contestó; Revilla asegura que guardó silencio obedeciendo las indicaciones que le hiciera al respecto, el ministro italiano en México. En realidad Landesio tenía razón en la mayoría de sus puntos de vista, en tanto que Ignacio Manuel Altamirano se dejaba llevar por los impulsos de su pasión nacionalista y republicana, la cual le impidió, por cierto, comprender el valor de la obra de Velasco; y no es que se crea que la política está, o debiera estar, reñida con el arte; no, lo que sucede es que en ocasiones las pasiones ideológicas van más allá de lo que es el ser mismo de la obra de arte, de lo que es su esencia primordial: la creación estética. El propio Altamirano tiene, dentro de su obra crítica, conceptos valiosísimos sobre la función estética de las obras de arte, sean éstas literarias o plásticas. Por otra parte, el tiempo vino a demostrar que a Landesio asistía la razón, cuando proponía que Velasco fuera el que ocupara su puesto en la Academia; Salvador Murillo fracasó rotundamente como pintor; primero en la propia Academia como maestro, 17 después en Europa a donde el gobierno le envió para que se perfeccionara en la pintura de paisaje. En París terminó, nos dice Revilla, dejando "los pinceles, dándose al oficio de cicerone de los mexicanos que arribaban a Francia". ${ }^{18}$

17 En La Tribuna, en el número 21, correspondiente al 28 de enero de 1874, AItamirano incluyó esta noticia que nos da idea de cómo andaban las cosas para su amigo y protegido: "PIntura de parsajz. Se nos ha informado que a la cátedra de paisaje que desempeña actualmente en la Academia de Bellas Artes, el distinguido pintor, señor don Salvador Murillo, concurren solamente tres alumnos. No comprendemos esta esquivez de nuestros jóvenes dedicados al culto del divino arte, por este ramo de la pintura tan importante y tan bello".

18 Op. cit., p. 318. 
Hasta donde nuestras posibilidades lo han permitido hemos investigado sobre la obra teórica y crítica que Eugenio Landesio escribió en México; nada más aparte de lo hasta aquí anotado, se ha encontrado en las publicaciones de esos años. Las líneas que en 1877 redactó a propósito del gran cuadro México, de Velasco y que Luis Islas García reproduce, ${ }^{10}$ en realidad obedecieron a que en dicha obra él veía la culminación tanto de sus gustos estéticos, como, asimismo, el más noble aprovechamiento de sus teorias pedagógicas; a este respecto Justino Fernández dice, en conclusión, que al cuadro "lo elogia porque responde en todo a las reglas del arte y a su buena observación de la naturaleza", 20 justo aquello por lo que tanto se habia esforzado como pintor y como maestro.

Para los fines de este trabajo, noticias interesantes deben encontrarse en la correspondencia que el maestro sostuvo desde Europa, con los amigos que aquí dejó. Parte considerable de esa correspondencia fue dirigida a José María Velasco; mas por desgracia nada se sabe de su existencia, es de desear que algún día aparezca y se publique. El insustituíble Revilla, transcribe unas lineas de algunas de esas cartas; ellas nos dan una idea de cuál fue la impresión que recibió el paisajista ante las nuevas corrientes pictóricas que encontró en Europa: "He visitado en Milán la exposición permanente, mediante la cual puedo tener una idea del arte actual. Noto en muchos la tendencia a abreviar las cosas; pero hay también en otros, de mayor poder, la de desarrollar toda la idea, como en un bello discurso, dejando a un lado las expresiones abreviadas; y mucho me alegré al ver que sacan más copias de estos últimos pintores que de los primeros. Esto demuestra que el gusto por lo bueno, no tan sólo no se ha extinguido, sino que se sobrepone al otro". 21 Todo comentario está de más, él permanecía atado a una tradición que le era tan cara y esencial. ¿Cuál fue el impacto que le causó el arte francés cuando visitó en compañía de su viejo amigo Clavé, la Exposición Universal de París de 1878? La respuesta debe estar en las cartas remitidas a Velasco, si es que éstas existen aún; recuérdese que para tal fecha las telas de los pintores impresionistas estaban a la orden del dia, su tercera exposición, celebrada en 1877 , les había asegurado, con cierta ventaja, el éxito que buscaban para su escuela.

10 Islas García, Luis. Velasco. Pintor Cristiano. México, Ed. "Proa", 1932. pp. 34-35.

20 En El Hombre..., p. 47.

21 Revilla, op. cit., pp. 318.19. 
Excursión a la caverna de Cacahuamilpa y ascensión al cráter del Popocatépetl, con este título publicó Eugenio Landesio, en 1868, un opúsculo que escribió a propósito de las excursiones que hizo a esos sitios. Por el criterio del artista que es lo que se impone en las descripciones de sus experiencias, el opúsculo debe sumarse a su obra teórica y critica.

Si grande era la fama de que disfrutaban en Europa, tanto las Grutas de Cacahuamilpa como el Popocatépetl, lo cierto es que no era menor el interés que movía a los viajeros que arribaban al país, para visitar estos lugares, pese a las dificultades que ello representaba. Las descripciones escritas, las pinturas y litografías que sobre estos dos sitios nos dejaron los visitantes extranjeros del siglo pasado, son numerosas y a cual más llenas de interés. La fama de las grutas la había escuchado Landesio desde Italia; sin embargo, pasaron algunos años de su residencia en México, antes de que pudiera conocerlas. Con anterioridad a él dos pintores las habían explorado, en 1835 el Barón Gros y en 1846 Pelegrín Clavé en compañía del escultor español Manuel Vilar; uno y otro dejaron obras sobre las bellezas de las grutas; Clavé después de haberlas vistado "dibujó y dio a luz algunas litografías...", según el propio Landesio, y el Barón Gros pintó un cuadro interesante inspirado en una de las grandes salas subterráneas. ${ }^{22}$ Acompañado del escultor Miguel Noreña, Landesio visitó las grutas, a las que calificó entusiasmado, de Museo Subterráneo; las caprichosas conformaciones naturales le parecieron hechas, nada menos, que con el mármol estatuario de Carrara; algunas de las apreciaciones hechas por Clavé, las corrigió, sin dejar de censurarle. De esta visita, al parecer, pintó dos cuadros que aparecen fechados hasta 1869: Salón de los Órganos y Salón de los Monumentos; sobre los mismos Velasco dibujó las dos litografías que ilustran la parte referente a este viaje, en el opúsculo.

Para la ascensión al cráter del Popocatépetl, movieron a Landesio, más que otra cosa, intereses de orden científico desde el punto de vista de un pintor teórico y lleno de preocupaciones por todo aquello que se presentase como obstáculo o supuestos problemas, respecto a la pintura del paisaje; en una pequeña introducción él mismo se encarga de informarnos de las razones que le movieron para llegarse hasta la nevada cima del volcán:

22 Romero de Terreros, Manuel. Marqués de San Francisco. El Barón Gros y sus vistas de México. Imprenta Universitaria. México, 1953. 
"... y más que nada del efecto, según me había asegurado una persona, que con motivo de la corta cantidad de atmósfera existente sobre uno, y su gran refracción hace que en lugar de azulado parezca negro el cielo, se avivó más mi deseo de visitar el volcán... Este último fenómeno interesábame sobre todo y le quería averiguar de preferencia; y aunque lo hubiera oído de persona no competente para hacer una apreciación de esta naturaleza, porque aunque buen físico y químico no era pintor; y para tal apreciación se necesita un pintor y un pintor general de mucha experiencia, que sea el mismo tiempo teórico y práctico, porque de otra manera, aunque pintor, estaría sujeto a miles de ilusiones y equivocaciones; sin embargo, había despertado en mi una duda, y un ardiente deseo, una necesidad de aclararla".

Como un teórico implacable respecto a la disciplina que practica, se presenta Landesio en esta descripción de su ascenso al Popocatépetl, teórico siempre dispuesto a desentrañar los misterios de la pintura del paisaje... desde sus propios principios, claro está. Ni el Barón Gros, ni mucho menos Johann Moritz Rugendas, se plantearon problemas semejantes para subir al volcán y pintarlo posteriormente. Landesio hizo la ascención en compañía del pintor José Obregón y del fotógrafo francés Charnie, quien tomó, por cierto, las primeras vistas estereoscópicas del interior del cráter. Con anterioridad Pelegrín Clavé había intentado subir también al volcán, más la altura se lo impidió.

Para ilustrar esta parte del opúsculo, Velasco litografió por encargo del autor, las vistas siguientes: El Popocatépetl. Sacado desde el Cerro de Tlamaca y El Popocatépetl. Su cráter visto desde el labio S.E. mirando hacia N.O. Estas litografías no son más que copias de los cuadros que pintó el propio Landesio.

Un papel de especial significación es el que corresponde a Eugenio Landesio, en el arte mexicano, como teórico de la pintura académica del siglo xIx. Sus tratados sobre perspectiva y la pintura de paisaje o "general" como él la llamaba, fueron las primeras obras de tal índole que en México se publicaron, si hacemos caso omiso de algunas ideas teóricas que se encuentran en el Diccionario manual de voces técnicas de Bellas Artes (1848), escrito por el Conde de la Cortina, ${ }^{23}$ obra como se ve, más de consulta general que no asi de enseñanza escolar.

23 Diccionario manual de voces técnicas castellanas de Bellas Artes. Por El Conde de la Cortina y de Castro. México. Imprenta de Vicente García Torres. 1848. 
Todos los principios que un buen pintor académico requiere, para el ejercicio pleno de sus actividades, se encuentran indicados celosamente en las obras de Landesio. Para él no hay artista cabal si éste no ha adquirido a conciencia, los cimientos que deben normar su formación y disponerle para la tarea creadora. Por ello censura a los maestros de las academias de bellas artes, que no han atendido con esmero la formación de los jóvenes aspirantes a pintores.

Con un espíritu muy moderno, de hombre del siglo xix, el maestro italiano unió la práctica a la teoría para que hubiera constancia de la eficacia de sus enseñanzas, en la vieja Academia de San Carlos. Aquí conviene no olvidar que sus tratados él los escribió para todo aquél que fuera a dedicarse al arte pictórico, no obstante que él enseñaba como especialidad la pintura de paisaje, pero a ésta la consideraba superior a otro género, por los diversos elementos que entran en la composición de un cuadro de paisaje; en atención a esto la llamó también "general", por oposición a lo particular que puede haber, por ejemplo, en la pintura de retrato o de asunto religioso que, dicho sea de paso, era lo que enseñaba en la propia Academia, su amigo el catalán Pelegrín Clavé.

De sus tratados se desprende que para la creación artística, según él la entendía, existen unas leyes invariables que son posibles de comunicar a los alumnos en formas de recetas, pero sin permitirles libertad alguna hasta en tanto no hayan asimilado, con la práctica constante y sin ninguna sombra de pereza, las lecciones comprendidas en los manuales y en las clases bajo la sabia dirección del maestro. Tal método, hoy lo sabemos, resulta antipedagógico, pero, no obstante, tuvo su razón de ser y debe tenerse presente en la historia de la enseñanza en México.

La critica de arte que escribió Eugenio Landesio, es un producto indisoluble de su labor teórica; para entenderle como crítico, hay que tener presentes los principios que sustentó tanto en la práctica como en la teoria artística. En la crítica él exigia, ante todo, que la pintura fuera entendida como tal, es decir, como una obra estética debida a una disciplina de oficio y a unos cimientos o principios, de los cuales era necesario que participara el crítico de arte, para que así pudiera hablar con autoridad sobre lo que tratara. Indudable razón le asistia, pero, en el fondo, Landesio partía de la idea tradicional y común, sobre todo entre los artistas, de que únicamente están capacitados para hablar de pintura, los propios pintores y asimismo los escultores y arqui- 
tectos para sus respectivas artes. De ahí resulta, también, que para él, la crítica de arte era un problema de tipo moral, ¿pues cómo se puede hablar de tal o cual arte, si se desconocen las bases de sus principios y valores? Es por ello que Landesio opinaba que en los juicios de los seudo-críticos, había mucho de falsedad; máxime si tales críticos eran hombres de letras que se habían improvisado para practicar la crítica sin más, y una vez en funciones, alteraban el valor de las obras y sembraban la confusión, entre la opinión pública, con la audacia de sus juicios y palabrería que nada, o muy poco, tienen que ver con las obras de arte.

En realidad Landesio no puntualiza si en su crítica se refiere tácitamente a lo que llamaremos crónicas de Ios periodistas, o si lo hace en forma abierta en contra de todo escritor, sin importarle la cultura que puedan tener los literatos a quienes acusa y condena sin más; el artista se olvidó o ignoró, que las mejores obras de crítica artística han sido escritas por autores que nunca ejercieron tal o cual arte plástico en particular, pero que poseían, en cambio, una sólida y amplia cultura aunada a una extraordinaria sensibilidad que estaba siempre abierta a la captación de los valores estéticos. Landesio era un hombre culto y refinado, pero quien sabe hasta qué punto se pueda asegurar si él conoció o no, los libros de Winckelmann, Lessing o Diderot, para no señalar sino a los autores más difundidos de su época y que no eran, a semejanza suya, artistas plásticos. Ahora bien, si sus censuras estaban encaminadas en contra de un literato del tipo de Ignacio Manuel Altamirano, no son del todo justas, pues es indudable que en la crítica de arte del siglo xIx mexicano, la voz de Altamirano es una de las más conscientes y acordes a su momento histórico, justo por la amplitud de su cultura.

En cuanto al contenido o mensaje de la obra de arte, esto era secundario para él, todo un representante, nada menos, que de la escuela del paisaje histórico, lo importante era pintar la historia como cosa muerta, como ruinas románticas; pero eso sí, pintar bien tanto ruinas como paisajes, de acuerdo con unas normas académicas. El contenido de las obras que tanto interesaba a Altamirano y a otros críticos de la época, para Landesio era cosa secundaria, él representaba, por decirlo así, la corriente esteticista del arte por el arte, frente a un arte comprometido que era el que exigía, a fin de cuentas, Altamirano. 